\title{
Implementation of UTAUT and D\&M Models for Success Assessment of Cashless System
}

\author{
Made Denny Oktariyana* Dodik Ariyanto and Ni Made Dwi Ratnadi \\ Faculty of Economics and Business, University of Udayana, Denpasar, Indonesia
}

\begin{abstract}
This study discusses the success of applying the Cashless System using the Unified Theory of Acceptance and Usage of Technology (UTAUT) model and the DeLone \& McLean (D \& M) model to assess human factors and technological factors in behavioral intention and influence them on individual performance. This study was designed to discuss the application of technology after the Cashless System was implemented for two years. The Cashless system is a special non-cash payment system for premium payment and insurance claims systems that used agents as payment agreements. Cashless systems are implemented based on the Financial Services Authority (OJK) and Bank of Indonesia Regulations (PBI) regulations concerning payment system services and consumer protection payment system services. The research location was chosen at AJB Bumiputera 1912 in Bali Province which was the first insurance company and invited in Indonesia. The research sample used purposive sampling with the criteria of all active users using the Cashless System, which is as many as 45 people. Data collection used a questionnaire distributed to 15 offices of AJB Bumiputera 1912 in Bali Province. Data analysis used Partial Least Square (PLS) with Structural Equation Modeling (SEM). The test results used the UTAUT model show that the performance of expectations, social influences apply positively to behavioral intentions of using the Cashless System. Expectations of effort were not applied to behavioral intentions of using the Cashless System. The test results used the D \& M model that shows the information quality, the information systems quality, service quality that had positive effect on behavioral intention of using Cashless System. The intention of behavior of using the Cashless System has positive effect on individual performance.
\end{abstract}

Keywords: UTAUT, Delone \& McLean, Cashless System

DOI: $10.7176 /$ RJFA/10-12-16

Publication date:June $30^{\text {th }} 2019$

\section{Introduction}

Bumiputera 1912 Joint Life Insurance (AJB) implements a non-cash premium payment system, where premium payments were previously made through agent intermediaries. This system change was made due to an appeal from the Financial Services Authority (OJK) dated 28 May 2015 No: S-53 / D05 / 2015 signed by the Executive Head of Nonbank Financial Industry Supervision (IKNB) regarding "Obligations of consumers of financial service institutions to have bank accounts in the context of monitoring the financial services sector, deepening financial markets, expanding access to public finance, and preventing money laundering. Consumers, participants, or customers are required to conduct financial transactions through the banking system ". Circular issued by the Financial Services Authority (OJK) also refers to Bank Indonesia Regulation No: 14/3 / PBI / 2012 concerning Anti Money Laundering (APU) and Prevention of Terrorism Funding (PPT) Programs for the provision of payment system services other than Bank and No regulation. : 16/1 / PBI / 2014 concerning, protection of consumer payment system services.

Factors that influence the success of system utilization can be done by evaluating using a model. Evaluation is one of the important aspects needed to determine the success of the implementation of an information system. Through evaluation, information will be obtained about the extent to which the achievement of the objectives of the system is successful and also feedback to improve the quality of the system in the future.

This research focuses on measurement after the implementation of the Cashless System. Seeing the problems that occur, this study uses two theoretical models in determining the success of a very well-known accounting information system. The two theories are the Unified Theory of Acceptance and Usage of Technology (UTAUT) model, and Delone \& McLean (D \& M) Information System Success Model. The UTAUT model examines the effect of constructs on behavioral interests, not yet attributed to results of use (Venkatesh et al., 2003). The construct is the expectations expected by users of information systems for repeated or routine use, so that the expected performance of users of the system becomes more effective and efficient. Predictors used in the study are, the interest of using a cashless system that is influenced by performance expectancy. How high a person believes that using a system will help him to provide benefit his work performance, effort expectancy is a level of convenience associated with the use of a system, social influence which is the influence of the work environment on individuals to use the system (Jogiyanto, 2007). 
In the $\mathrm{D} \& \mathrm{M}$ model, interest of using information systems is determined by information quality, system quality, and service quality (DeLone and McLean, 2003). Users feel how a system provides useful facilities that influence usage interest and connect it to individual performance. Information quality is a predictor of the output quality of the Cashless System. System information quality to be a predictor of the amount of computer technology is felt to be relatively easy to understand and use. Service quality as a predictor of overall assessment of the superiority of a service provided by the Cashless System.

These two models can find out the impact of using the system by internal users or company employees. The division of determinants into two classifications. They are human and technology. Users or humans need to be evaluated because they are related to the system directly. Technology needs to be evaluated because it is part of the system.

The advantages of this research test the success of a system using the UTAUT model and the D \& M model which is a measure of human factors and technological factors. This research focuses on the renewal of the application of a cashless system, especially in the system of premium payments and insurance claims that used to use agents as intermediaries. The research location was chosen in the AJB Bumiputera 1912 Province of Bali which was the first and oldest insurance company in Indonesia which had just begun to implement a noncash payment system.

\section{Theory Review and Hypothesis Development}

\subsection{Theory of Reasoned Action}

Theory of Reasoned Action (TRA) describes the behavior change based on the outcome of the behavior and intentions of behavior is influenced by social norms and individual attitudes toward behavior (Ajzen and Fishbein, 1980). The behavior observed in this study is the acceptability of the user in the application Cashless System. Ajzen (1991) which says that attitudes influence behavior through a rigorous decision-making process and reasoning as well as its impact is limited to three things; First, the behavior is largely determined by the general attitudes but by the specific attitude towards something. Second, the behavior is influenced not only by attitudes but also by the norms of objective (subjective norms) that our belief about what other people want us to do. Third, the attitude towards a shared behavioral norm of subjective form a specific intention or intention to behave.

\subsection{Unified Theory of Acceptance and Use of Technology}

The Unified Theory of Acceptance and Use of Technology (UTAUT) is based on theories of the use of technology and technology acceptance. Venkatesh et al. (2003) said technology acceptance behavior has several factors, such as, (1) Performance expectancy is defined as an action whereby someone believes that using the system will help him to achieve performance gains. (2) Effort expectancy is defined as the degree of ease associated with using the system. (3) Social influences are defined as the extent to which an individual view the importance of his work environment factors (in this case the social sphere) on the use of new system. (4) Facilitating condition is defined as the level at which someone believes that an organization and technical infrastructure are there to support the use of the system. (5) Behavior intention is the main behavior of the organization in receiving technology. Consistent with the theory underlying all influences on behavioral intention, it is expected that behavioral intention will have a significant influence on the use of technology. (6) Use behavioral is the behavior that achieved of using technology.

\subsection{D\&M Information System Success Model}

Implementation of an information system is doomed to failure or success in the application, this can be caused by two aspects, namely technical and non-technical aspects (Jogiyanto, 2007). The first aspect is the technical aspects, the aspects related to the system itself which is the technical quality of the information system. While the second aspect is the non-technical aspects, namely about the perception of users of information systems that cause users unwilling or reluctant to use information systems that have been developed. Thus, the need for an approach to test the success of information systems for detecting failures of a system. DeLone and McLean (2003) states, six factors on which the success of an information system that is information quality, system quality, service quality, intention to use, user satisfaction, individual impact and impact organization.

\subsection{Hypothesis Development}

2.4.1 The Influence of Performance Expectancy on Behavioral Intention

Performance expectancy is defined as how high a person believes that using a system will help him to get performance benefits in his job (Jogiyanto, 2007). This concept describes the benefits of the system for the 
wearer related to perceived usefulness, extrinsic motivation, job fit, the relative advantage (Venkatesh et al., 2003). Based on the theory of reasoned action, reaction and perception of the use of information systems will affect the manner in receipt of the information system. The results show that performance expectancy affects behavioral intention. These results are supported by Pertiwi and Ariyanto (2017); Amna and Istiasih (2017); Ariyanto et al. (2017) prove that performance expectancy has a positive effect on behavioral intention or intention to use. Information systems can provide positive things in their use when the information system makes it easier for someone to improve performance. Therefore, the first hypothesis of this study is:

\section{$\mathrm{H}_{1}$ : Performance expectancy has a positive effect on behavioral intention}

\subsubsection{The Influences of Effort Expectancy on Behavioral Intention}

Effort expectancy is defined as the level of ease associated with using a system. If the system is easy to use, the work done will not be too high, and vice versa if a system is difficult to use the high effort required to use it (Jogiyanto, 2007). The results showed that the effort expectancy affects behavioral intention. This result was supported by Ariyanto et al. (2017); Amna and Istiasih (2017); Mediyanto and Mahendra (2017). The ease of use of technology or information systems will give rise to feelings in a person that the system has uses and hence creates a sense of comfort when working with it. Therefore, the second hypothesis of this study is:

\section{$\mathrm{H}_{2}$ : Effort expectancy has a positive effect on behavioral intention}

\subsubsection{Social Influence on Behavioral Intention}

Social influence is defined as the level at which an individual assumes that other people convince him that he must use a new system (Triandis, 1980). In an organizational environment, social influence will determine the success of the use of information systems. The behavior will be influenced by social rules that rely on messages received from others and influence the mind of someone doing their work (Triandis, 1980). The results showed an effect of social influence on behavioral intention. These results are supported Ariyanto et al. (2017); Amna and Istiasih (2017); Mediyanto and Mahendra (2017) show that social influence is an important element in adopting and using information technology systems that will improve the behavioral intention. Social influences include the encouragement of management and colleagues are working to individuals to use information systems so that users are motivated to use the system. Therefore, the third hypothesis of this study is:

\section{H3: Social influence has a positive effect on behavioral intention}

\subsubsection{The Influences of Information Quality on Behavioral Intention}

Information quality can be defined as the quality of information that is the result of data processing. Quality information at least meet four criteria: accurate, timely, relevant, and complete. Similarly, the information obtained from the Cashless System. High and low quality of the information would affect the use of technology by employees. The relationship between information quality on the behavioral intention to use information systems have a positive influence (DeLone and McLean, 2003). This result is supported by Admaja (2014); Utami and Samopa (2013); Supriyono (2017) who shows information quality has a positive effect on behavioral intention. Information quality is the degree to which the characteristics that provide value to the user. Size behavioral intention on information systems is reflected by the quality of information produced by the system. Behavioral intention of an information system is how users view information in real systems and not on the quality system in engineering. If the information system users believe that the information generated from the system is optimal, they will use the system. Therefore, the fourth hypothesis of this study is:

\section{H4: Information quality has a positive effect on behavioral intention}

\subsubsection{The Influences of System Information Quality on Behavioral Intention}

System information quality is the level of perceived how much computer technology is relatively easy to understand and use. Quality systems and quality of information, individually and together, affecting user satisfaction and usage (Davis et al., 1989). Studies that use the construct of D \& M show the positive influence of information system quality on behavioral intention is research conducted by Admaja (2014); Utami and Samopa (2013); Supriyono (2017). System information quality is getting better by giving fleksibility, ease of use, system reliability will improve the behavioral intention to use information systems. If, the determining 
factors are met then the system implemented will improve the behavioral intention to use the system continuously. Therefore, the fifth hypothesis of this study is:

\section{H5: System information quality has a positive effect on behavioral intention}

\subsubsection{The Influences of Service Quality on Behavioral Intention}

Service quality can be determined by comparing the user's perception of the real system that they have received or acquired by the service they expect or want (Baridwan and Hanum, 2007). The concept of quality of service meets the expectations of service expected if equal to that felt satisfying means for users on service quality provided by the software application provider information system (Susanto, 2005). The results showed service quality has a positive influence on behavioral intention. These results are supported Utami and Samopa (2013); Supriyono (2017); Marselia et al. (2018). If the information system users feel that the service quality provided by the provider of accounting application program package is good, then it will tend to be satisfied using the system. Predicted that the higher the quality of services provided will influence the high level of behavioral intention of using the system. Therefore, the sixth hypothesis of this study is:

H6: Service quality has a positive effect on behavioral intention

\subsubsection{The Influences of Behavioral Intention on Individual Performance}

The behavior of a person is an expression of desire or interest of a person where the desire is influenced by social factors, feelings and perceived consequences suggests that the benefits perceived by users will increase their interest to use information systems (Davis et al., 1989). Individual performance is the behavioral effects of adoption and utilization of accounting information systems at individual users of information technology in organizations. Confidence someone will usefulness of the information system will increase their interest and in the end people will use the information system in its work (Thompson et al., 1991). Studies that use the construct of $\mathrm{D} \& \mathrm{M}$ show the positive influence between behavioral intention on the individual performance of the research done Admaja (2014); Utami and Samopa (2013); Supriyono (2017); and Nurlani and Permana (2017). Relationships interest utilization and use of information systems is the intensity or frequency of the user of using information technology to achieve optimum performance. Therefore, the seventh hypothesis of this study is:

\section{H7: Behavioral intention has a positive effect on Individual Performance}

\section{Research Methods}

The population of this study was official employees in AJB Bumiputera 1912 in the Province of Bali who used the accounting information system namely Cashless System in their work. The employees selected in this study were Branch Heads, Head of Financial Administration Unit, Finance Section and Cashier, Administration Section, and Claim Section. The sampling method used purposive sampling method with the criterion that all users actively involved in the use Cashless System, which includes the Administration Unit Head of Finance, Administration, Claims Section, and Section cashier. The number of respondents in the research samples were 49 respondents. Based on 49 questionnaires distributed to 15 AJB Bumiputera 1912 Provinces of Bali, the questionnaires returned were only 45 , so this study only used 45 samples. 
Table 1. Construct of Research

Operational

\begin{tabular}{|c|c|c|c|c|}
\hline Construct & Definition & Indicators & $\begin{array}{l}\text { Item } \\
\text { Code }\end{array}$ & Source \\
\hline $\begin{array}{l}\text { Performance } \\
\text { Expectancy } \\
\quad(\mathrm{PE})\end{array}$ & $\begin{array}{l}\text { Performance expectancy is defined as how high a } \\
\text { person believes that using a system will help him to } \\
\text { gain advantages in job performance }\end{array}$ & $\begin{array}{l}\text { 1. Perceived usefulness } \\
\text { 2. Productivity } \\
\text { 3. Extrinsic Motivation } \\
\text { 4. Efectivity } \\
\text { 5. Job fit } \\
\text { 6. Relative Advantage }\end{array}$ & $\begin{array}{l}\text { PE1 } \\
\text { PE2 } \\
\text { PE3 } \\
\text { PE4 } \\
\text { PE5 } \\
\text { PE6 }\end{array}$ & $\begin{array}{l}\text { Davis et al. } \\
\text { (1989); } \\
\text { Vankatesh et al. } \\
\text { (2003) }\end{array}$ \\
\hline $\begin{array}{l}\text { Effort } \\
\text { Expectancy } \\
(\mathrm{EE})\end{array}$ & $\begin{array}{l}\text { Effort expectancy is defined as the level of } \\
\text { convenience as sociated with the use of a system. If } \\
\text { the system is easy to use, the work done will not be } \\
\text { too high, and vice versa if a system is difficult to } \\
\text { use the high effort required to use it. }\end{array}$ & $\begin{array}{l}\text { 1. Perceived ease of use } \\
\text { 2. Ease of use } \\
\text { 3. Complexity } \\
\text { 4. Time Utility } \\
\text { 5. Trust }\end{array}$ & $\begin{array}{l}\text { EE1 } \\
\text { EE2 } \\
\text { EE3 } \\
\text { EE4 } \\
\text { EE5 }\end{array}$ & $\begin{array}{l}\text { Davis et al. } \\
\quad(1989) ; \\
\text { Vankatesh et } \\
\text { al. }(2003)\end{array}$ \\
\hline $\begin{array}{l}\text { Social } \\
\text { Influence } \\
\quad(\mathrm{SI})\end{array}$ & $\begin{array}{l}\text { Social influence is defined as the extent to which an } \\
\text { individual perceives the interest that is trusted by } \\
\text { other people who will influence it using the new } \\
\text { system }\end{array}$ & $\begin{array}{l}\text { 1. Partner support } \\
\text { 2. Manager support } \\
\text { 3. Leader support } \\
\text { 4. Organizational support }\end{array}$ & $\begin{array}{l}\text { SI1 } \\
\text { SI2 } \\
\text { SI3 } \\
\text { SI4 }\end{array}$ & $\begin{array}{l}\text { Thompson et al. } \\
\qquad(1991) \text {; } \\
\text { Vankatesh et al. } \\
\text { (2003) }\end{array}$ \\
\hline $\begin{array}{l}\text { Information } \\
\text { Quality } \\
\text { (IQ) }\end{array}$ & $\begin{array}{l}\text { Information quality is defined as the quality of the } \\
\text { output of an information system. }\end{array}$ & $\begin{array}{l}\text { 1. Relevancy } \\
\text { 2. Accuracy } \\
\text { 3. Timeliness } \\
\text { 4. Reliability }\end{array}$ & $\begin{array}{l}\text { IQ1 } \\
\text { IQ2 } \\
\text { IQ3 } \\
\text { IQ4 }\end{array}$ & $\begin{array}{c}\text { DeLone dan } \\
\text { McLean (2003) }\end{array}$ \\
\hline $\begin{array}{l}\text { System } \\
\text { Information } \\
\text { Quality } \\
\text { (SIQ) }\end{array}$ & $\begin{array}{l}\text { The quality of information systems is perceived } \\
\text { ease of use which is how much computer } \\
\text { technology is felt to be relatively easy to } \\
\text { understand and use. }\end{array}$ & $\begin{array}{l}\text { 1. Fleks ibility } \\
\text { 2. Ease of use } \\
\text { 3. System Reliability }\end{array}$ & $\begin{array}{l}\text { SIQ1 } \\
\text { SIQ2 } \\
\text { SIQ3 }\end{array}$ & $\begin{array}{c}\text { DeLone dan } \\
\text { McLean (2003) }\end{array}$ \\
\hline $\begin{array}{l}\text { Service Quality } \\
\text { (SQ) }\end{array}$ & $\begin{array}{l}\text { Quality of service is a thorough assessment of the } \\
\text { benefits of a service. Quality of service is described } \\
\text { as a statement of attitude, relationships resulting } \\
\text { from the comparis on between the expectations of } \\
\text { the performance. }\end{array}$ & $\begin{array}{l}\text { 1. Tangibles } \\
\text { 2. Reliability } \\
\text { 3. Responsiveness } \\
\text { 4. Assurance } \\
\text { 5. Empathy }\end{array}$ & $\begin{array}{l}\text { SQ1 } \\
\text { SQ2 } \\
\text { SQ3 } \\
\text { SQ4 } \\
\text { SQ5 }\end{array}$ & $\begin{array}{c}\text { DeLone dan } \\
\text { McLean (2003) }\end{array}$ \\
\hline $\begin{array}{l}\text { Behavioral } \\
\text { Intention } \\
\text { (BI) }\end{array}$ & An interest in someone to do a particular behavior. & $\begin{array}{l}\text { 1. Has helpful features } \\
\text { 2. Always try to use } \\
\text { 3. Continues in the future }\end{array}$ & $\begin{array}{l}\text { BI1 } \\
\text { BI2 } \\
\text { BI3 }\end{array}$ & $\begin{array}{l}\text { Davis et al. } \\
\quad(1989)\end{array}$ \\
\hline $\begin{array}{l}\text { Individual } \\
\text { Performance } \\
\text { (IP) }\end{array}$ & $\begin{array}{l}\text { Individual performance is the behavioral effects of } \\
\text { adoption and utilization of information systems on } \\
\text { individual users of information technology in } \\
\text { organizations. }\end{array}$ & $\begin{array}{l}\text { 1. Realization of increased } \\
\text { individual productivity } \\
\text { 2. Important and valuable } \\
\text { contribution } \\
\text { 3. Improving the quality of } \\
\text { decision making }\end{array}$ & $\begin{array}{l}\text { IP1 } \\
\text { IP2 } \\
\text { IP3 }\end{array}$ & $\begin{array}{c}\text { DeLone dan } \\
\text { McLean (1992) }\end{array}$ \\
\hline
\end{tabular}

Table 1 describes the study on the definition of variables, indicators, and sources used in the measurement variable. Data analysis was performed by the SmartPLS 3 application using the Structural Equation Modeling method. 


\section{Results of Statistical Analysis}

4.1 Evaluation of Outer Model

Evaluation of the measurement model or outer model carried out to examine the relationship manifest variables or indicators that are used with the latent variables. Evaluation is done by using the outer models PLS Algorithm calculations is presented in Figure 1.

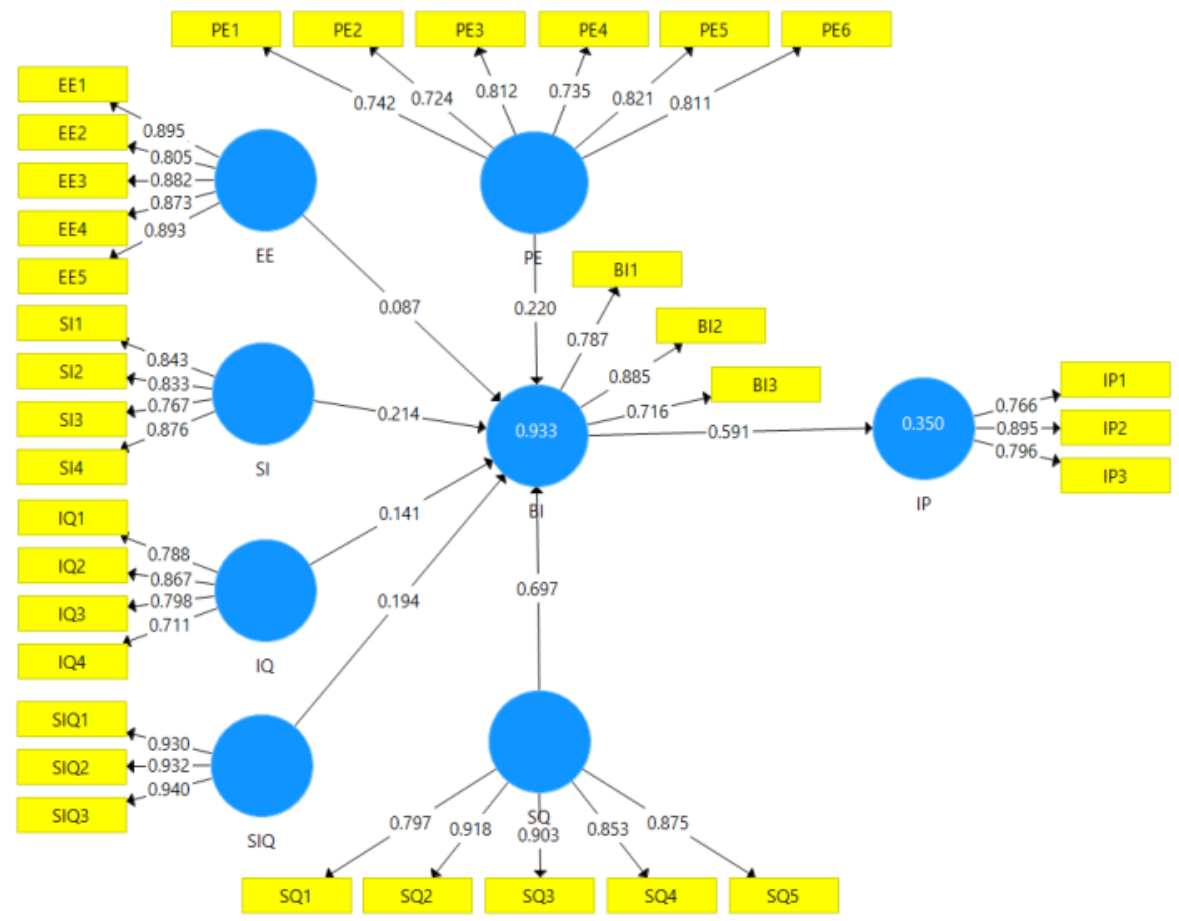

Figure 1: Empirical Model of PLS Algorithm

Convergent validity with a reflexive indicator can be seen from the correlation between the score and the score variable indicator. Based on test results convergent validity, the whole outer loading indicator value has a value above 0.50 . This means that the measurement meets the requirements of convergent validity, the validity of the data.

Rate discriminant validity is to compare the average variance extracted for each variable with correlation between variables with other variables in the model. The test results showed that the discriminant validity of the entire variable value AVE is greater than 0.50 so that the model can be said to be valid.

Reliability testing variables are measured by two criteria, namely composite reliability and Cronbach's alpha of blocks of indicators that measure variables. The test results of composite reliability and Cronbach's alpha indicates the value of all the variables above 0.70 so that it can be explained that all the research variables are reliable. 


\subsection{Evaluation of Inner Model}

Testing the hypothesis of a direct effect done using $\mathrm{t}$ statistic and $\mathrm{p}$ values and the calculated results bootstrapping. The results of bootstrapping analysis can be seen in Table 1 and Figure 2.

\begin{tabular}{cccccc}
\multicolumn{5}{c}{ Table 1: Direct Effect Test Results } \\
\hline No. & $\begin{array}{c}\text { Relationship } \\
\text { Between Variables }\end{array}$ & $\begin{array}{c}\text { Path Coefficient } \\
\text { (Bootstrapping) }\end{array}$ & T Statistic & P Value & Description \\
\hline $\mathbf{1}$ & $\mathrm{PE} \rightarrow \mathrm{BI}$ & 0,220 & 2,931 & 0,002 & Significant \\
$\mathbf{2}$ & $\mathrm{EE} \rightarrow \mathrm{BI}$ & 0,087 & 0,995 & 0,160 & Not Significant \\
$\mathbf{3}$ & $\mathrm{SI} \rightarrow \mathrm{BI}$ & 0,214 & 2,930 & 0,002 & Significant \\
$\mathbf{4}$ & $\mathrm{IQ} \rightarrow \mathrm{BI}$ & 0,141 & 2,220 & 0,013 & Significant \\
$\mathbf{5}$ & $\mathrm{SIQ} \rightarrow \mathrm{BI}$ & 0,194 & 2,725 & 0,003 & Significant \\
$\mathbf{6}$ & $\mathrm{SQ} \rightarrow \mathrm{BI}$ & 0,697 & 8,611 & 0,000 & Significant \\
$\mathbf{7}$ & $\mathrm{BI} \rightarrow \mathrm{IP}$ & 0,591 & 6,897 & 0,000 & Significant \\
\hline
\end{tabular}

Source: Primary Data Processed, 2019

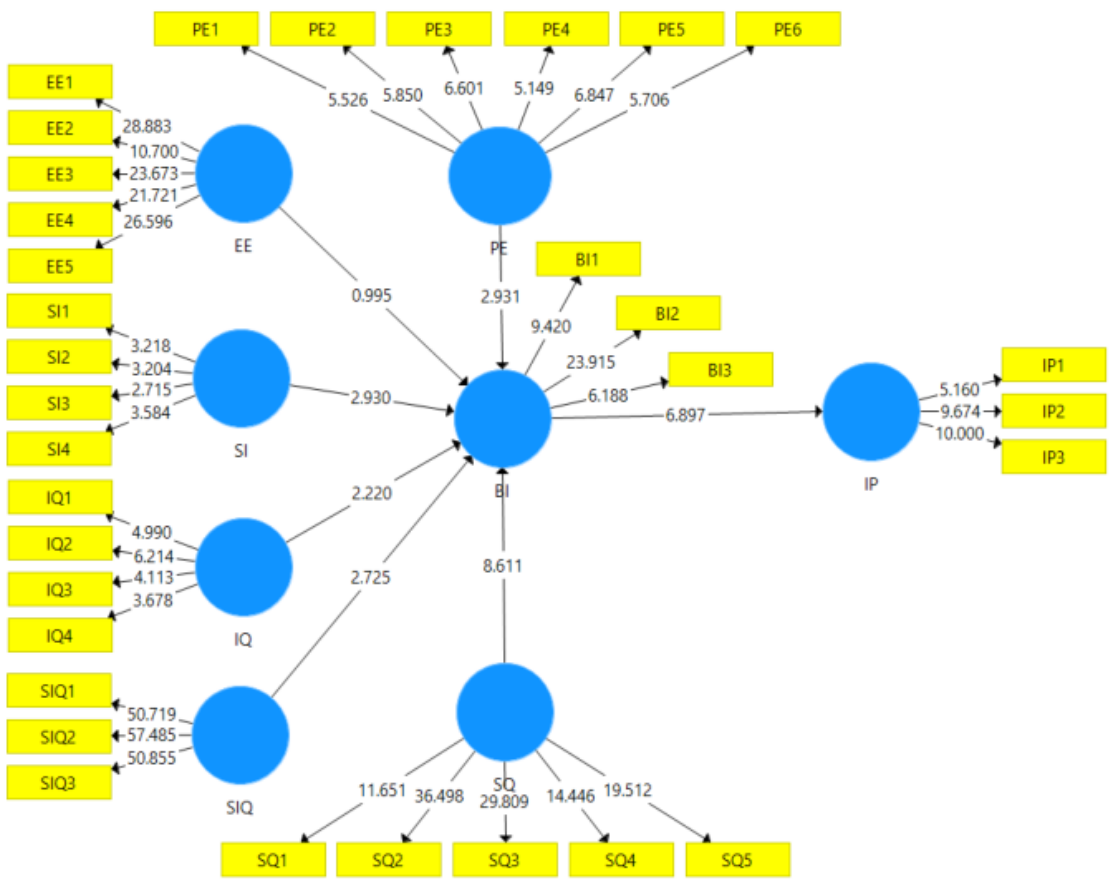

Figure 2: Bootstrapping of Reseacrh Variables

Hypothesis testing results indicate that the Performance Expectancy (PE), Social Influence (SI), Information Quality (IQ), System Information Quality (Siq), Service Quality (SQ) has a positive effect on Behavioral Intention (BI) of using Cashless System with $t$ statistic more than 1.96 and $p$ values less than five percent. The Effort Expectancy (EE) indicator has no effect on Behavioral Intention of using the Cashless System with a statistical $t$ value of less than 1.96 and a $\mathrm{p}$ value of more than five percent. The test results Behavioral Intention (BI) of using Cashless System has a positive effect on the Individual Performance (IP) with statistical t over 1.96 and $p$ values of less than five percent. It shows 6 hypotheses are accepted and one hypothesis is rejected.

\section{Discussion}

5.1 The Influence of Performance Expectancy on Behavioral Intention

Performance expectancy has a positive effect on the behavioral intention of using the Cashless System in AJB Bumiputera 1912 in the Province of Bali. Positive path coefficient means that the higher the level of performance expectancy, the more behavioral intention of using the Cashless System. The results of this study are supported by the results of the study, Research Iriani et al. (2014); Widnyana and Yadnyana (2015); Pertiwi and Ariyanto (2017); Amna and Istiasih (2017); Ariyanto et al. (2017) prove that performance expectancy has a positive effect on behavioral intention. 
Performance expectancy is one's belief in the execution of a job which would be assisted if using a system. Jogiyanto (2007) defines performance expectancy as how high a person believes that using a system will help him to gain advantage in his job performance. User expectations after using Cashless System impact on productivity, effectiveness and makes it easier to do the job than before using Cashless System. Respondents gave the highest response on indicators of relative advantage. Relative advantage is the extent to which the new system provides a better impact than the old system. These results indicate that the employees of AJB Bumiputera 1912 in the Province of Bali discovered a new system namely Cashless System that is useful in their work, so that they will increase their interest of using the Cashless System on an ongoing basis.

\subsection{The Influences of Effort Expectancy on Behavioral Intention}

Effort expectancy has no significant effect on behavioral intention of using Cashless System. The results can be interpreted that the high and low levels of effort expectancy, it cannot affect the level of behavioral intention of using Cashless System. Expectations of business is in the research related to the use of information systems to facilitate the employee in his job. The results of this study indicate that the employees of AJB Bumiputera 1912 had not felt easy in operating the Cashless System and did not yet have confidence that the Cashless System could reduce their efforts both energy and time in completing work. According to Venkatesh and Davis, 2000, the use of information technology that is easy to create the perception that the system was useful to him and raises comfort when using it. However, if this system is difficult to use, the comfort of working with the system will not arise and the intention to use it to use the system will be less. Venkatesh et al. (2003) and Gaffar et al. (2013) also found the same thing with this study.

Respondents gave the lowest answers to the trust indicators that showed the confidence of employees of AJB Bumiputera 1912 found it difficult to be skilled of using Cashless Systems. Skilled is a picture of a person's ability level. Skilled in system utilization is the success in achieving effective and efficient goals that are determined by speed, accuracy, form and ability to adapt to the use of the system.

\subsection{Social Influence on Behavioral Intention}

Social influence has a positive effect on the behavioral intention of using the Cashless System in AJB Bumiputera 1912 in the Province of Bali. Positive path coefficient means that the higher the level of social influence, the behavioral intention of using the Cashless System will increase. The results of this study are supported by research of Yadnyana and Wulandari (2016); Amna and Istiasih (2017); Mediyanto and Mahendra (2017); Ariyanto et al. (2017) prove that social influence has a positive effect on behavioral intention. Jogiyanto (2007) describes a social influence as the extent to which an individual perceives the interest that is trusted by other people who will influence it using the new system. The support given by managers, supervisors and coworkers in AJB Bumiputera 1912 to motivate users of the system to use the system. The respondent gave the highest answer to the manager's support indicators which showed that the Head of the Financial Administration Unit (KUAK) helped use the Cashless System. This means that the implementation support and guidance provided by KUAK helps users master the application of the Cashless System so that users feel motivated to continue using the Cashless System in their work.

\subsection{The Influence of Information Quality on Behavioral Intention}

Information quality has a positive effect on the behavioral intention of using the Cashless System in AJB Bumiputera 1912 in the Province of Bali. Positive path coefficient means that the higher the level of information quality, the behavioral intention of using the Cashless System will increase. The results of this study are supported by the results of the study, Admaja (2014); Utami and Samopa (2013); Supriyono (2017) proves that information quality has a positive effect on behavioral intention. Information quality is the extent to which information can consistently meet the requirements and expectations of all people who need that information to carry out their processes. The results of the information provided by the Cashless System provide data that is relevant, accurate, timely and reliable to its users.

Respondents gave the highest response on indicators of reliability, it indicates Cashless System is very reliable, this is reflected in the resulting data is free of errors or accurately provide information about the payment of premiums and insurance claims. The high quality of information produced by the Cashless System has a positive impact on the behavioral intention so that users will continue to use the system in their work in AJB Bumiputera 1912 Bali Province. 
5.5 The Infuences of System Information Quality pada Behavioral Intention

System information quality has a positive effect on the behavioral intention of using the Cashless System in AJB Bumiputera 1912 in the Province of Bali. Path coefficient is positive, meaning that the higher the level of information quality system, the behavioral intention of using Cashless System will increase. The results of this study are supported by Admaja (2014); Utami and Samopa (2013); Supriyono (2017) proved the system information quality has a positive effect on behavioral intention. System quality is a measurement of information system processes that focus on the results of interactions between users and systems. System quality has attributes such as flexibility, ease of use and system reliability are determinants of why an information system is used or not used. If, the determining factors are met then the system implemented will improve the behavioral intention to use the system continuously.

Respondents gave the highest response on indicators of reliability means Cashless System has met the expectations of its users by providing flexibility ease of use, and reliability of the system. This shows Cashless System has functions that are specific to fund premiums and payment of claims, so that meet user expectations impacting system users will continue to use the Cashless System in support operations in AJB Bumiputera 1912, Bali Province.

5.6 The Influences of Service Quality on Behavioral Intention

Service Quality has a positive effect on the behavioral intention of using the Cashless System in AJB Bumiputera 1912 in the Province of Bali. Positive path coefficient means that the higher the level of service quality given, the behavioral intention of using the Cashless System will increase. The results of this study are supported by Utami and Samopa (2013); Supriyono (2017); Marselia et al. (2018) that proves service quality has a positive effect on behavioral intention. Susanto (2005) states, the concept of service quality meets the expectations of service expected if equal to that felt satisfying means for users on service quality provided by the information system software application provider. The service quality is composed of comprehension, assurance, tangible, empathy and reliability.

Respondents gave the highest response on assurance indicators which means users safe in accessing or sending data through Cashless System. Features of the service quality provided Cashless System meets the expectations of employees AJB Bumiputera 1912. Services provided in the form of a menu display that allows users to access needed services, help services that provide features help or guidance of using systems and services for the error correction of user input Cashless System. The service is causing users feel satisfied with the service Cashless System and improve the behavioral intention to use sustainably Cashless System to improve its performance in 1912 Bali Province.

\subsection{The Influences of Behavioral Intention on Individual Performance}

Behavioral intention has a positive effect on individual performance in AJB Bumiputera 1912 in Bali Province. Positive path coefficient means that the higher behavioral intention, the individual performance will increase. The results of this study were supported by Admaja (2014); Utami and Samopa (2013); Supriyono (2017); and Nurlani and Permana (2017) who prove behavioral intention has a positive effect on individual performance. Jogiyanto (2007) states, after implementing the system, the strengths and weaknesses of the system are known, attitudes are found to have a greater influence on interest. When the system has been operationalized, informational influences will be more effective in fostering interest than through normative influences. This proves that after the system is implemented it will affect behavioral intention so that it has an impact on user efficiency.

The respondent gave the highest answer on the indicator to continue in the future which means that the user expects to continue to use the Cashless System in his work. Cashless System after the implementation users have to know the advantages and disadvantages perceived. Many advantages are given compared to weaknesses after the implementation of Cashless System, thus increasing behavioral intention of using the Cashless System continuously and having a positive impact on the effectiveness and productivity of employees of AJB Bumiputera 1912.

\section{Conclusions and Suggestions}

The test results using UTAUT models show that performance expectancy, social influence has a positive effect on behavioral intention of using Cashless System. Effort expectancy has no effect on behavioral intention of using Cashless System. The test results using the model of D \& M shows information quality, system 
information quality, service quality has a positive effect on behavioral intention of using Cashless System. Behavioral intention of using Cashless System has a positive effect on individual performance.

The limitations of this study only describe the internal users of the Cashless System in AJB Bumiputera 1912 in the Province of Bali so that it does not describe the use of the customer as the party conducting transactions through the Cashless System service. Suggested for further research using other models such as: UTAUT2 that examines the user's interest in the context of information systems of customers or clients.

\section{References}

Admaja, A. F. S. 2014. Analisis Kesuksesan Sistem Informasi Manajemen Sumber Daya dan Perangkat Pos dan Informatika (SIMS) An Analysis of Information System Success for SIMS (Sistem Informasi Manajemen SDPPI). Buletin Pos dan Telekomunikasi, 12(2), pp. 105-118.

Ajzen, I. 1991. The theory of planned behavior. Organizational Behavior and Human Decision Processes. doi: 10.1016/0749-5978(91)90020-T.

Ajzen, I. dan Fishbein, M. 1980. Theory Of Reasoned Action / Theory Of Planned Behavior. The Journal of Social Psychology. doi: 10.4018/jcit.2006100102.

Amna, A. R. dan Istiasih, H. 2017. Analisis Penerimaan User Sistem Informasi Akuntansi Menggunakan Model Unified Theory of Acceptance and Use of Tecnology (UTAUT). Generation Journal. ISSN: 25804952.

Ariyanto, D., Putri, I.G.A.M.A.D., Ratnadi, N.M.D., Sujana, I Ketut. dan Ariartha, I.B.O. 2017. Successful Adoption of E-Monitoring for Budgeting Implementation in Context of Mandatory Environment and Tri Hita Karana Culture. Research Journal of Finance and Accounting, Vol 8, No 9.

Aryanto, D., Maria M, R.S. dan Ratnadi, N.M.D. 2017. Budaya Tri Hita Karana Dalam Model UTAUT. Jurnal Akuntansi Multiparadigma (JAMAL), 8, pp. 227-429. doi: 10.1002/9781119179313.wbprim0302.

Baridwan, Z. dan Hanum, L. 2007. Kualitas Dan Efektivitas Sistem Informasi Berbasis Komputer. Universitas Brawijaya.

Davis, F. D. 1989. Perceived Usefulness, Perceived Ease of Use, and User Acceptance of Information Technology. MIS Quarterly. doi: 10.2307/249008.

Davis, F. D., Bagozzi, R. P. dan Warshaw, P. R. 1989. User Acceptance of Computer Technology: A Comparison of Two Theoretical Models. Management Science. doi: 10.1287/mnsc.35.8.982.

DeLone, W. H. dan McLean, E. R. 2003. The Delone And Mclean Model of Information Systems Success: A ten-year update. Journal of Management Information Systems, 19(4), pp. 9-30. doi: 10.1080/07421222.2003.11045748.

Gaffar, K., Singh, L., dan Thomas, T. D. 2013. The Utility of the UTAUT Model in Explaining Mobile Learning Adoption in Higher Education in Guyana. University of Guyana, Guyana

Iriani, S. Suryanto, M. dan Amborowati, A. 2014. Pengujian Sistem Informasi Pengelolaan Keuangan Daerah Berbasis Web Kabupaten Pacitan Dengan Menggunakan Unified Theory Of Acceptance And Use Of Technology (UTAUT). IJNS - Indonesian Journal on Networking and Security, 3(2), pp. 60-66.

Jogiyanto. 2007. Sistem Informasi Keperilakuan. Yogyakarta: BPFE Yogyakarta, edisi ke enam.

Marselia, S., Sulistiowati dan Lemantara, J. 2018. Analisis Kesuksesan Website E-Learning Management System (EMS) Dengan Menggunakan Model Delone dan McLean Pada Cabang Primagama Bumi Citra Fajar (BCF). JSIKA. Vol. 7, No. 1. Tahun 2018. ISSN: 2338-137X.

Mediyanto, B. dan Mahendra, I. 2017. Penerapan Metode UTAUT Untuk Memprediksi Behavioral Intentions Use Dalam Menggunakan Aplikasi ZABBIX. Journal Ilmu Pengetahuan dan Teknologi Komputer, 3(1), pp. 9-16.

Nurlani, L. dan Permana, B. 2015. Analisa Kesuksesan Sistem Informasi Akademik Menggunakan Model Terintegrasi. Jurnal Teknologi Rekayasa, 2(2), pp. 105-116.

Pertiwi, N. W. D. M. Y. and Ariyanto, D. 2017. Penerapan Model UTAUT2 Untuk Menjelaskan Minat dan Perilaku Penggunaan Mobile Banking di Kota Denpasar. E-Jurnal Akuntansi Universitas Udayana. ISSN: 2302-8556, Vol 18, pp:1369-1397.

Supriyono. 2017. Analisis Kesuksesan Sistem Informasi Perpustakaan di Universitas Negeri Yogyakarta (UNY) Dengan Pendekatan Model Delone Dan Mclean. Jurnal Pendidikan Teknik Informatika Universitas Negeri Yogyakarta, (1), pp. 1-10.

Susanto, A. (2005) Sistem Informasi Akuntansi. Jakarta: PT. Lingga Jaya.

Thompson, R. L., Higgins, C. A. dan Howell, J. M. 1991. Personal Computing: Toward a Conceptual Model of Utilization. MIS Quarterly, 15(1), p. 125. doi: 10.2307/249443.

Triandis, H. C. 1980. Values, attitudes, and interpersonal behavior. Nebraska Symposium on Motivation. doi: 10.1016/S0969-4765(04)00066-9. 
Utami, A. W. dan Samopa, F. 2013. Analisa Kesuksesan Sistem Informasi Akademik di Perguruan Tinggi dengan Menggunakan D \& M IS Success Model (Studi Kasus: ITS Surabaya). Jurnal Sistem Informasi, 4(5), pp. 294-309. doi: 10.24089/j.sisfo.2013.09.001.

Venkatesh, V., Morris, M.G., Davis., G.b. dan Davis., F.D. 2003. User Acceptance of Information Technology: Toward a Unified View. MIS Quarterly, Vol 27, No 3, pp: 425-478, doi: 10.2307/30036540.

Venkatesh, V. dan Davis, F. D. 2000. A Theoretical Extension of the Technology Acceptance Model: Four Longitudinal Field Studies. Management Science, 46(2), pp. 186-204.

Widnyana, I. D. G. P. dan Yadnyana, I.K. 2015. Implikasi Model Utaut Dalam Menjelaskan Faktor Niat Dan Penggunaan SIPKD Kabupaten Tabanan. E-Jurnal Akuntansi Universitas Udayana, ISSN: 2302-8556, pp: 515-530.

Wulandari, N.P.A., dan Yadnyana, I. K. 2016. Penerapan Model Unified Theory of Acceptance and Use of Technology di Kota Denpasar. E-Jurnal Akuntansi Universitas Udayana. Pp: 1270-1297. doi: 10.1109/TUFFC.2010.1411. 